\title{
AMMONIA-FREE NOx CONTROL SYSTEM
}

\section{QUARTERLY TECHNICAL PROGRESS REPORT NO. 41865R5}

OCTOBER 1 THROUGH DECEMBER 31, 2004

Prepared by

Song Wu and Zhen Fan

Foster Wheeler North America Corp.,

and

Richard G. Herman

Energy Research Center, Lehigh University

Issued: January 31, 2005

Work Performed Under Contract: DE-FC26-03NT41865

For

U.S. Department of Energy

National Energy Technology Laboratory

Morgantown, West Virginia

By

Foster Wheeler North America Corp.

12 Peach Tree Hill Road

Livingston, New Jersey 07039 


\section{Disclaimers}

"This report was prepared as an account of work sponsored by an agency of the United States Government. Neither the United States Government nor any agency thereof, nor any of their employees, makes any warranty, express or implied, or assumes any legal liability or responsibility for the accuracy, completeness, or usefulness of any information, apparatus, product, or process disclosed, or represents that its use would not infringe upon privately owned rights. Reference herein to any specific commercial product, process, or service by trade name, trademark, manufacturer, or otherwise does not necessarily constitute or imply its endorsement by the United States Government or any agency thereof. The views and opinions of authors expressed herein do not necessarily state or reflect those of the United States Government or any agency thereof."

Neither the author, nor any affiliate, nor any of their employees, makes any warranty, express or implied, or assumes any legal liability or responsibility including, but not limited to, in regard to the accuracy, completeness, or usefulness of any information, apparatus, product, or process disclosed, or represents that its use would not infringe upon privately owned rights whether such liability or responsibility is of a direct, indirect, special, punitive, incidental, consequential, or other nature and whether arising in contract, warranty, tort including negligence, strict liability, or other legal theory. Utilization of this information is with the above understanding. 


\title{
AMMONIA-FREE NOx CONTROL SYSTEM
}

\author{
TECHNICAL PROGRESS REPORT NUMBER 41865R5 \\ FOR OCTOBER THROUGH DECEMBER 2004
}

\begin{abstract}
$\underline{\text { Abstract }}$
Research is being conducted under United States Department of Energy (DOE) Contract DEFC26-03NT41865 to develop a new technology to achieve very low levels of NOx emissions from pulverized coal fired boiler systems by employing a novel system level integration between the PC combustion process and the catalytic NOx reduction with $\mathrm{CO}$ present in the combustion flue gas. The combustor design and operating conditions will be optimized to achieve atypical flue gas conditions. This approach will not only suppress NOx generation during combustion but also further reduce NOx over a downstream catalytic reactor that does not require addition of an external reductant, such as ammonia.
\end{abstract}

This report describes the work performed during the October 1 to December 30, 2004 time period. 


\section{Table of Contents}

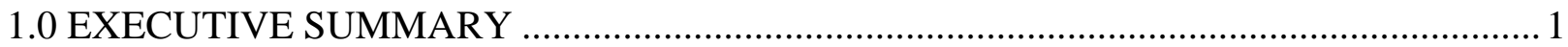

1.1 Project Overview

1.2 Progress During the Quarter ...................................................................... 1

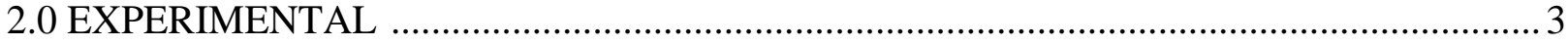

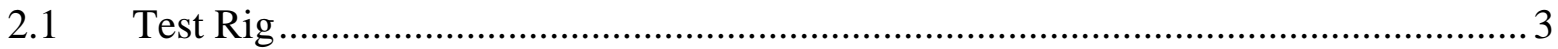

2.2 Catalyst Preparation ................................................................................... 4

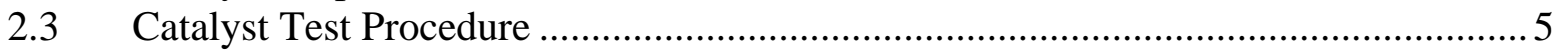

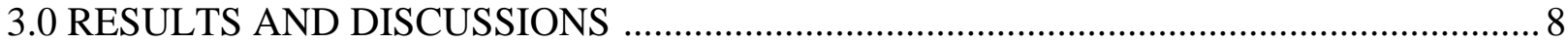

3.1 Reaction Pathways .................................................................................... 8

3.2 Performance of AL Based Catalysts .............................................................. 8

3.3 Testing with High Space Velocity ....................................................................... 14

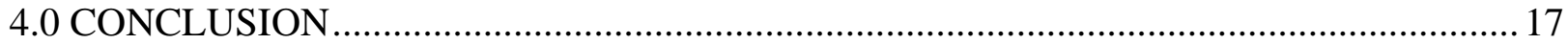

\section{List of Figures}

Figure 1 Bench Scale NOx Testing System .................................................................

Figure $2 \mathrm{NO}, \mathrm{CO}$ and $\mathrm{O}_{2}$ Conversions over the $40 \% \mathrm{Fe} / 30 \% \mathrm{Cu} / \mathrm{AL}$ Catalyst $\mathrm{N}$.................. 9

Figure 3 Conversion of $\mathrm{NO}, \mathrm{CO}$, and $\mathrm{O}_{2}$ over the $40 \% \mathrm{Fe} / 30 \% \mathrm{Cu} / \mathrm{AC}$ Catalyst .................. 9

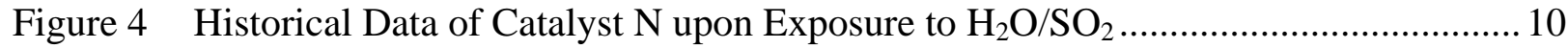

Figure 5 Transient NO Concentrations before and after the Start of Water Addition ..............11

Figure 6 Historical Data of Type $\mathrm{O}$ Catalyst upon Exposure to $\mathrm{H}_{2} \mathrm{O} / \mathrm{SO}_{2} \ldots \ldots \ldots \ldots \ldots \ldots \ldots \ldots \ldots . . . . . . . . . .12$

Figure $7 \quad \mathrm{NO}$ Conversion for $\mathrm{N}$ and $\mathrm{O}$ Catalysts ........................................................ 13

Figure $8 \quad \mathrm{NO}$ to $\mathrm{N}_{2} \mathrm{O}$ Conversion for $\mathrm{AC}$ and $\mathrm{AL}$ Catalysts ............................................. 14

Figure 9 Effect of Space Velocity on NO Conversion for AC and AL Catalysts ...................15

Figure $10 \mathrm{NO}, \mathrm{CO}$ and $\mathrm{O}_{2}$ Conversions over Previously Tested (P) and Fresh (Q) $40 \% \mathrm{Fe} / 30 \% \mathrm{Cu} / \mathrm{AL}$ Catalyst with GHSV $=5250 \mathrm{hr}^{-1}$

$\underline{\text { List of Tables }}$

Table 1 Catalyst Samples Tested ................................................................................... 7

Table 2 BET Surface Area (m2/g) of Type N and O Catalysts .......................................... 12 


\subsection{EXECUTIVE SUMMARY}

\subsection{Project Overview}

State-of-the-art NOx control technology for pulverized coal (PC) steam plants involves a combination of low NOx combustion and selective catalytic reduction (SCR) technologies. Development of these systems has approached a plateau and further improvements will likely be incremental. To advance NOx control technology to the next level, new concepts must be considered.

The objective of this project is to evaluate the viability of a novel integration between the PC combustion process and flue gas NOx reduction. The concept exploits the relationship between $\mathrm{CO}$ and NOx both in the combustion and flue gas NOx destruction processes to achieve very low levels of NOx from the boiler system without adding any external reductant, such as ammonia, typically used for SCR processes.

The project starts with a review and evaluation of commercial and developmental catalysts for NOx reduction and $\mathrm{CO}$ oxidation, including those catalysts formulations successfully used in the automotive applications, for their use in PC power plants. This knowledge, combined with prior catalyst research experience for power plant applications allows the project team to identify and test catalyst formulations robust enough for the oxidizing flue gas environment in power plants, and capable of achieving competitive NOx reduction performance and economic targets.

A detailed PC combustion study, applying computational fluid dynamics simulation program to perform boiler and burner design modeling, complements the catalyst development effort by investigating ways to optimize the combustion process for the lowest NOx formation while generating sufficient levels of $\mathrm{CO}$ needed by the downstream catalytic NOx reduction process. Furnace configuration, air staging, and burner design are evaluated in this process.

The study will then focus on the comparative evaluation of a conceptual, 400 MWe, coal-fired PC boiler system, utilizing this novel NOx control concept. For this evaluation, the concept plant will be compared to a traditional PC boiler configured with current low NOx combustion technology and an ammonia-based SCR system. The comparison will involve conceptual level design of the furnace and catalyst reduction system to obtain equipment pricing, operational costs, performance data as well as qualitative reliability information.

\subsection{Progress During the Quarter}

The project work during this quarter was the continuation of Task 2 - Catalyst Testing. Work during the previous quarter was focused on testing of activated carbon (AC) based catalysts, and on Task 3 - Furnace Optimization. During this quarter, a new group of activated alumina (AL) based catalysts has been studied in detail under conditions similar to the prior test with AC based catalysts. The goal of Task 2 was to screen and characterize candidate catalyst samples conceived and prepared through in-depth literature study and development work by the project team. 
The AL based catalysts were made using either as received or calcined activated alumina as substrate, and loaded with the best performing active metal formulation from the previous tests with AC based catalysts. The catalysts were prepared by aqueous incipient impregnation method and tested on the bench scale catalyst test rig at Lehigh University. Tests were conducted in reactant gas mixtures with or without moisture and $\mathrm{SO}_{2}$. To provide further information for catalytic reactor design, an AL based catalyst and an AC based catalyst were tested using a high gas hourly space velocity (GHSV).

The AL supported base metal catalysts have shown very promising NOx conversion and selectivity in oxidizing environment with $\mathrm{CO}$ as reductant, as well as excellent $\mathrm{CO}$ reduction. It is recommended that both the AL and AC groups of catalysts be further developed and tested at pilot scale, for long duration, and with actual combustion flue gas. 


\subsection{EXPERIMENTAL}

\subsection{Test Rig}

A fixed bed reactor at Lehigh University was the main experimental tool employed in this study. The catalyst testing system featured a vertical down flow quartz tube reactor (10.5 mm ID x 13 mm OD). Temperature in the reactor was monitored by an axial thermocouple located in the catalyst bed. The tip of the thermocouple is usually positioned 2.5 to $5.5 \mathrm{~cm}$ below the top of the catalyst bed. Heating was accomplished with a vertical split-tube furnace surrounding the reactor. The gas stream inlet and outlet 316 stainless steel sections were wrapped with heating tapes and insulation and heating was controlled by two Variacs. Temperatures of the inlet and outlet lines were monitored by six thermocouples and maintained above $100^{\circ} \mathrm{C}$.

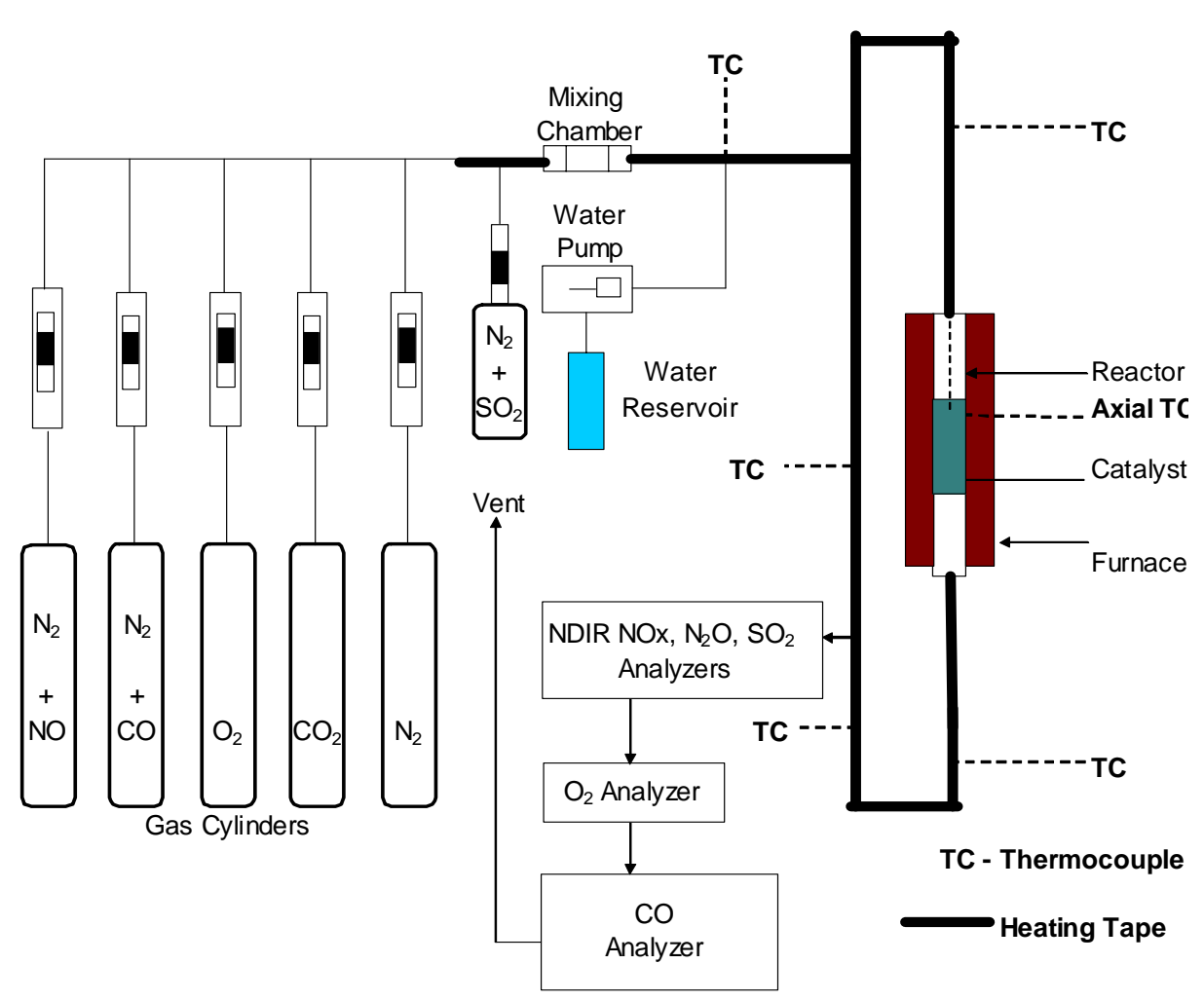

Figure 1 Bench Scale NOx Testing System

A process flow diagram of the NO reduction test rig is shown in Figure 1. Approximately $20 \mathrm{ml}$ of weighed catalyst sample was placed in the reactor and supported by a quartz wool plug. Based on literature survey, the CO-NO reaction under study is not catalyzed by the quartz reactor tube at temperatures below $1000^{\circ} \mathrm{C}$. Individual gas flow meters were used to regulate flow rates from gas cylinders containing $\mathrm{NO} / \mathrm{N}_{2}, \mathrm{CO} / \mathrm{N}_{2}, \mathrm{O}_{2}, \mathrm{CO}_{2}, \mathrm{~N}_{2}$, and $\mathrm{SO}_{2} / \mathrm{N}_{2}$ to simulate flue gas from coalfired power plants. A cylinder pump was used to inject desired amount of distilled water through 
a vaporizing pipe section into the heated inlet gas line to the reactor. The outlet test gas goes through a chiller before entering the gas analyzers. A bypass valve can be used to connect the inlet gas stream directly to the analyzers to check and confirm the inlet concentrations of NO and other gases. A bubble flow meter was used to calibrate the rotameters for individual gas streams.

Analysis of the $\mathrm{NO}, \mathrm{N}_{2} \mathrm{O}$, and $\mathrm{SO}_{2}$ concentrations in the gas stream were achieved with a Siemens Ultramat 6 non-dispersive infrared (NDIR) analyzer, while $\mathrm{O}_{2}$ was analyzed by a Siemens Oxymat 6 Paramagnetic analyzer. CO was determined by a Testo 325-3 digital CO analyzer. Monitoring of these gases in the reactor inlet and outlet streams was carried out to determine if these components of the gas mixture were being generated or consumed. Moisture $\mathrm{CO}_{2}$, and $\mathrm{N}_{2}$ concentrations were calculated based on their flow rates into the reactor.

\subsection{Catalyst Preparation}

The activated carbon (AC) used in this study was a 12-20 mesh size product purchased from Aldrich. It was lignite-derived, designated as Darco Activated Carbon and manufactured by American Norit Co. Due to its relatively low cost, lignite-based activated carbon has been widely used in the waste to energy industry for trace pollutant removal, and is currently being demonstrated to capture mercury for coal fired utility plants. The BET surface area of an "as received" AC sample was determined (6-point analysis) by nitrogen adsorption at $-196^{\circ} \mathrm{C}$ using a Micromeritics Gemini 2360 V1.03 instrument. Before analysis, the sample was purged with flowing $\mathrm{N}_{2}$ while heating from $60^{\circ} \mathrm{C}$ to $200^{\circ} \mathrm{C}$ over a period of $55 \mathrm{~min}$. The sample was then maintained at $200^{\circ} \mathrm{C}$ for $2 \mathrm{hr}$ and cooled to ambient temperature. During this thermal treatment, the sample exhibited a $1.5 \mathrm{wt} \%$ loss of weight. The determined surface area of the activated carbon was $525 \mathrm{~m}^{2} / \mathrm{g}$. After loading of the catalytic components the surface area for catalyst Type B became $468 \mathrm{~m}^{2} / \mathrm{g}$, which is very close to that of the as received AC.

Another catalyst substrate used was activated alumina (AL). An 8-14 mesh size activated alumina (AL) product was obtained from Fisher Scientific. It was designated as A-505 adsorption grade alumina. The alumina was utilized either as received, or after calcining. The as received sample was simply purged with $\mathrm{N}_{2}$ and stored in a $\mathrm{N}_{2}$-filled glove bag containing a beaker of Drierite to maintain a dry atmosphere before catalyst preparation. To obtain a calcined sample, a portion of the alumina was placed in a porcelain evaporation dish and placed in a furnace at $180^{\circ} \mathrm{C}$. The temperature was increased to $500^{\circ} \mathrm{C}$, and the sample was held at this temperature overnight. It was then removed from the furnace, cooled, and placed in a $\mathrm{N}_{2}$-filled glove bag containing a beaker of Drierite to maintain a dry atmosphere. A small portion of the activated alumina in a separate dish with the same calcination treatment exhibited a $14.4 \% \mathrm{wt}$ loss. The BET surface areas of the alumina samples used as substrate are given in Table 2.

The preparation procedure of the AL catalyst followed that utilized previously for the $\mathrm{Fe} / \mathrm{Cu} / \mathrm{AC}$ catalysts, by an impregnation method. Reagent grade chemicals of metal nitrates from Fisher Scientific (ACS Certified) or Strem Chemcials were dissolved in distilled water and heated to $60^{\circ} \mathrm{C}$. To the solution was added $\mathrm{AL}$ while maintaining constant stirring. The solution was then evaporated over a period of a few hours, and when the solid was dry to the touch, it was placed in a plastic bottle. The open plastic bottle was placed in an $\mathrm{N}_{2}$-filled glove bag containing a beaker of Drierite desiccant for further drying. 
Activation of catalysts was carried out by decomposition of metal salts. The impregnated multimetal nitrate salts were decomposed by heating under established flow rates of the simulated gas mixture containing approximately 3.0\% $\mathrm{O}_{2}, 14 \% \mathrm{CO}_{2}, 520 \mathrm{ppm} \mathrm{CO}$, and balance $\mathrm{N}_{2}$. The gas hourly space velocity (GHSV) used for the decomposition treatment was about $930 \mathrm{hr}^{-1}$. The inlet and exit lines as well as the furnace were then heated. Usually, the catalyst was slowly heated to about $270^{\circ} \mathrm{C}$ over a period of 3-6 hr and maintained at this temperature for $0.5-3 \mathrm{hr}$ until the emitted NO achieved low levels.

During this treatment, a large amount of NO was released from the catalyst, as a result of nitrate salt decomposition, which peaked in the temperature range of $100-200^{\circ} \mathrm{C}$ and then decreased with further increase of temperature and time of equilibration. $\mathrm{CO}, \mathrm{O}_{2}$, and $\mathrm{N}_{2} \mathrm{O}$ were also measured during decomposition/activation at increased temperatures. After the decomposition treatment, the furnace controller was turned off and only the flow of $\mathrm{N}_{2}$ was maintained overnight as the furnace cooled to ambient temperature.

\subsection{Catalyst Test Procedure}

For NO reduction activity determination, the flow rates of the gas mixture components were reestablished and the flow rates were measured/confirmed by means of a bubble meter. The reactor was then heated and the $\mathrm{NO} / \mathrm{N}_{2}$ flow was turned on. The temperature of the catalyst bed was then sequentially changed to obtain a conversion-temperature profile both in steady state and in transient conditions. To screen the performance of different catalysts, a constant GHSV of $1050 \mathrm{hr}^{-1}$ at ambient temperature and pressure and the inlet gas composition was used. The established dry reactant gas mixture consisted of the following for most of the tests:

$\begin{array}{lllll}\mathrm{NO} & \mathrm{CO} & \mathrm{O}_{2} & \mathrm{CO}_{2} & \mathrm{~N}_{2} \\ 260 \mathrm{ppm} & 520 \mathrm{ppm} & 3.0 \% & 14.0 \% & 83 \% .\end{array}$

This gas mixture gives a $\mathrm{CO} / \mathrm{NO}$ molar ratio of 2.0, with enough excess reductant for the NO reduction reaction. To study the catalyst reactivity for NO reduction without the interference of poisoning or inhibition, the initial catalyst evaluation tests were carried in the absence of $\mathrm{SO}_{2}$ and moisture. After the initial tests, selected catalysts were exposed to the reactant gas stream containing moisture and $\mathrm{SO}_{2}$ to determine inhibition and poisoning effects.

For experiments with moisture added to the gas stream, water was injected and vaporized to give the following reactant gas mixture with an overall GHSV of $1140 \mathrm{hr}^{-1}$ :

$\begin{array}{llllll}\mathrm{NO} & \mathrm{CO} & \mathrm{O}_{2} & \mathrm{H}_{2} \mathrm{O} & \mathrm{CO}_{2} & \mathrm{~N}_{2} \\ 240 \mathrm{ppm} & 480 \mathrm{ppm} & 2.8 \% & 8.0 \% & 12.9 \% & 76.3 \% .\end{array}$

When the reactant stream contained $\mathrm{SO}_{2}$, a $5727 \mathrm{ppm} \mathrm{SO} / \mathrm{N}_{2}$ mixture was utilized and its flow rate was compensated by decreasing the $\mathrm{N}_{2}$ flow rate accordingly to maintain the overall GHSV at $1140 \mathrm{hr}^{-1}$. The resultant reactant gas mixture consisted of:

$\begin{array}{lllllll}\mathrm{NO} & \mathrm{CO} & \mathrm{SO}_{2} & \mathrm{O}_{2} & \mathrm{H}_{2} \mathrm{O} & \mathrm{CO}_{2} & \mathrm{~N}_{2} \\ 240 \mathrm{ppm} & 480 \mathrm{ppm} & 200 \mathrm{ppm} & 2.8 \% & 8.0 \% & 12.9 \% & 76.3 \% .\end{array}$


Catalytic reactivity is expressed by conversions, where the calculated conversions are multiplied by 100 to obtain \% Conversion, i.e.

$$
\begin{array}{ll}
\mathrm{NO} & \text { Conversion }=1-(\mathrm{NO})_{\text {out }} /(\mathrm{NO})_{\text {in }} \\
\mathrm{N}_{2} \mathrm{O} & \text { Conversion }=2\left(\mathrm{~N}_{2} \mathrm{O}\right)_{\text {out }} /(\mathrm{NO})_{\text {in }} \\
\mathrm{CO} & \text { Conversion }=1-(\mathrm{CO})_{\text {out }} /(\mathrm{CO})_{\text {in }} \\
\mathrm{O}_{2} & \text { Conversion }=1-\left(\mathrm{O}_{2}\right)_{\text {out }} /\left(\mathrm{O}_{2}\right)_{\text {in }} \\
\mathrm{SO}_{2} & \text { Conversion }=1-\left(\mathrm{SO}_{2}\right)_{\text {out }} /\left(\mathrm{SO}_{2}\right)_{\text {in }}
\end{array}
$$

It was assumed that there was no significant difference between gas inlet and outlet in its molar flow rates, considering that about $97 \%$ of the dry feed gas is $\mathrm{N}_{2}$ or $\mathrm{CO}_{2}$, neither of which are expected to participate in any of the reactions under study here. The NO reduction levels were determined following attainment of steady state. As a post-combustion NO control process, a low NO level of 260 ppm was used in this test, assuming some form of low NOx combustion technology is already being used.

The temperature of the catalyst bed was changed and the NO conversion was determined as it approached to a steady state at each set point. The set point temperatures were selected to achieve the maximum NO reduction for each catalyst. The NOx conversion as a function of temperature and time were recorded. The other gases, such as $\mathrm{O}_{2}, \mathrm{CO}, \mathrm{SO}_{2}$, and $\mathrm{N}_{2} \mathrm{O}$, were also recorded. They are used to analyze catalytic selectivity, NOx reduction pathways, and possible side reactions, especially the relations among $\mathrm{NOx}$ reduction, $\mathrm{CO}$ depletion, and $\mathrm{O}_{2}$ consumption. The reactivity profile of NOx reduction vs. temperature can then be plotted to compare the performance from different catalysts.

After a test, the test sample was cooled down and preserved in an $\mathrm{N}_{2}$ environment for subsequent characterization. Most of the tested catalysts were subjected to repeat test(s) under identical conditions as used for the first day test. The multi-day tests ensure data/procedure repeatability and provide clues to any deactivation over time on stream.

Tests on various combinations of $\mathrm{Fe}, \mathrm{Cu}, \mathrm{Ce}$, and $\mathrm{K}$ on the $\mathrm{AC}$ and $\mathrm{AL}$ supports have been conducted. To date, 13 catalysts have been prepared and evaluated.

Table 1 describes the various catalyst samples tested. The amount of each metal impregnated on the AC or AL support is expressed as the percentage of a reference total metal loading. The test runs in this report are reported as a combination of letters and numbers, such as A-1, B-2, where the letter indicates the catalyst type tested and the number indicates the order of the test run, for example, 1 for first run (e.g. Day 1). Duplicate samples of some of the catalysts were tested under different conditions and designated with different names for convenience of reference. $\mathrm{P}$ is a sample of the remaining O catalysts after eight tests at a GHSV of 1050 1/hr. It is used for high GHSV testing at 5250 1/hr. 
Table 1. Catalyst Samples Tested*

\begin{tabular}{|c|c|c|c|c|}
\hline Catalyst Name & $\begin{array}{l}\text { First Test } \\
\text { Date }\end{array}$ & Catalyst Formula & GHSV, l/hr & Substrate \\
\hline $\mathrm{A}$ & $4 / 07$ & As-received AC & 1050 & $\mathrm{AC}$ \\
\hline $\mathrm{B}$ & $4 / 09$ & $10 \% \mathrm{Fe} / 10 \% \mathrm{Cu}$ & 1050 & $\mathrm{AC}$ \\
\hline $\mathrm{C}$ & $4 / 21$ & $40 \% \mathrm{Fe} / 10 \% \mathrm{Cu}$ & 1050 & $\mathrm{AC}$ \\
\hline $\mathrm{D}$ & $4 / 30$ & $10 \% \mathrm{Fe} / 30 \% \mathrm{Cu}$ & 1050 & $\mathrm{AC}$ \\
\hline $\mathrm{E}$ & $5 / 21$ & $40 \% \mathrm{Fe} / 0 \% \mathrm{Cu}$ & 1050 & $\mathrm{AC}$ \\
\hline $\mathrm{F}$ & $5 / 26$ & $7 \% \mathrm{Fe} / 7 \% \mathrm{Cu}$ & 840 & $\mathrm{AC}$ \\
\hline G & $5 / 29$ & $40 \% \mathrm{Fe} / 10 \% \mathrm{Cu}$ & 1050 & $\mathrm{AC}$ \\
\hline $\mathrm{H}$ & $6 / 09$ & $40 \% \mathrm{Fe} / 30 \% \mathrm{Cu}$ & 1050 & $\mathrm{AC}$ \\
\hline $\mathrm{I}$ & $6 / 22$ & Aqueous-treated AC & 1050 & $\mathrm{AC}$ \\
\hline $\mathrm{J}$ & $6 / 29$ & $\begin{array}{c}40 \% \mathrm{Fe} / 30 \% \mathrm{Cu} / 20 \% \\
\mathrm{Ce}\end{array}$ & 1050 & $\mathrm{AC}$ \\
\hline $\mathrm{K}$ & $7 / 22$ & $10 \% \mathrm{Fe} / 10 \% \mathrm{Cu} / 20 \% \mathrm{~K}$ & 1050 & $\mathrm{AC}$ \\
\hline L (duplicate of E) & $8 / 13$ & $40 \% \mathrm{Fe} / 0 \% \mathrm{Cu}$ & 1050 & $\mathrm{AC}$ \\
\hline $\mathrm{M}$ (duplicate of $\mathrm{H}$ ) & $9 / 02$ & $40 \% \mathrm{Fe} / 30 \% \mathrm{Cu}$ & 1050 & $\mathrm{AC}$ \\
\hline $\mathrm{N}$ & $10 / 04$ & $40 \% \mathrm{Fe} / 30 \% \mathrm{Cu}$ & 1050 & $\mathrm{AL}$ \\
\hline $\mathrm{O}$ & $11 / 05$ & $40 \% \mathrm{Fe} / 30 \% \mathrm{Cu}$ & 1050 & AL (calcined) \\
\hline $\begin{array}{c}\mathrm{P} \text { (previously } \\
\text { tested O) }\end{array}$ & $12 / 09$ & $40 \% \mathrm{Fe} / 30 \% \mathrm{Cu}$ & 5250 & AL (calcined) \\
\hline Q (duplicate of O) & $12 / 16$ & $40 \% \mathrm{Fe} / 30 \% \mathrm{Cu}$ & 5250 & AL (calcined) \\
\hline R (duplicate of H) & $01 / 07$ & $40 \% \mathrm{Fe} / 30 \% \mathrm{Cu}$ & 5250 & AL (calcined) \\
\hline
\end{tabular}

* Percentage in catalyst formula refers to a reference total loading. 


\subsection{RESULTS AND DISCUSSIONS}

\subsection{Reaction Pathways}

Literature review and test data analysis have revealed that the performance of the NO - catalyst CO system was influenced mainly by the following four competing reaction pathways:

1. Direct reduction of NO by $\mathrm{CO}$, either added in the test gas mixture or generated in situ from the AC support, i.e., $\mathrm{NO}+\mathrm{CO} \rightarrow \mathrm{N}_{2}+\mathrm{CO}_{2}$;

2. Destruction/oxidation of excess $\mathrm{CO}$, i.e., $\mathrm{CO}+\mathrm{O}_{2} \rightarrow \mathrm{CO}_{2}$;

3. Partial combustion/gasification of the supporting activated carbon, i.e., $\mathrm{C}+\mathrm{O}_{2} \rightarrow \mathrm{CO}+$ $\mathrm{CO}_{2}$; and,

4. Direct reaction of $\mathrm{NO}$ with the carbon support, i.e., $\mathrm{NO}+\mathrm{C} \rightarrow \mathrm{N}_{2}+\mathrm{CO}_{2}$

Depending on reaction temperature, type of substrate, and type / amount of metals applied, different reaction pathway(s) may dominate the performance under given operating conditions.

\subsection{Performance of AL Based Catalysts}

The catalysts tested in previous quarters were all activated carbon based. Beyond its function as a catalyst support, activated carbon also directly participate in reactions involving both NO and CO (reaction pathways 3 and 4 above), especially at higher temperatures. These two reactions are absent for activated alumina based catalysts. Therefore the AL based catalysts test data, together with earlier AC based test data, provide an opportunity to understand the interactions and relative importance the reactions in the NO- catalyst-CO system.

The first AL catalyst tested was Type $\mathrm{N}$, prepared using as-received activated alumina. Figure 2 summarizes the test data for Catalyst $\mathrm{N}$ on five separate days, in dry, $\mathrm{SO}_{2}$ free gas mixture as described in section 2.3. During Day 4 testing the catalyst was exposed to moisture and $\mathrm{SO}_{2}$, therefore Days 5 and 6 represent the catalyst performance in dry, $\mathrm{SO}_{2}$-free environment after the exposure.

NO and CO Conversion: The Days 1-3 test data for Catalyst $\mathrm{N}$ can be compared with the typical performance of AC-based catalysts with same metal loading (40\% $\mathrm{Fe}$ and $30 \% \mathrm{Cu}, \mathrm{M}$ and $\mathrm{H}$ ), shown in Figure 3. The AL catalyst reached 50\% NO removal in the temperature range of about 240-250, which was similar to the AC based catalysts. The AL catalysts also achieved over $80 \%$ NO removal, but at reaction temperatures about $20{ }^{\circ} \mathrm{C}$ higher than those of $\mathrm{AC}$ catalysts for the same NO conversion.

Both AL and AC catalysts gave excellent $\mathrm{CO}$ conversion over the entire temperature range. The fresh AL catalyst actually did slightly better (at about $90 \%$ conversion) than the AC catalyst. These data show that, even in the absence of carbon related reaction pathways 3 and 4, the $\mathrm{Fe} / \mathrm{Cu} / \mathrm{AL}$ catalyst is capable of $\mathrm{NO}$ and $\mathrm{CO}$ removal levels similar to that of AC based catalyst, albeit with a somewhat flatter NO - temperature profile. 


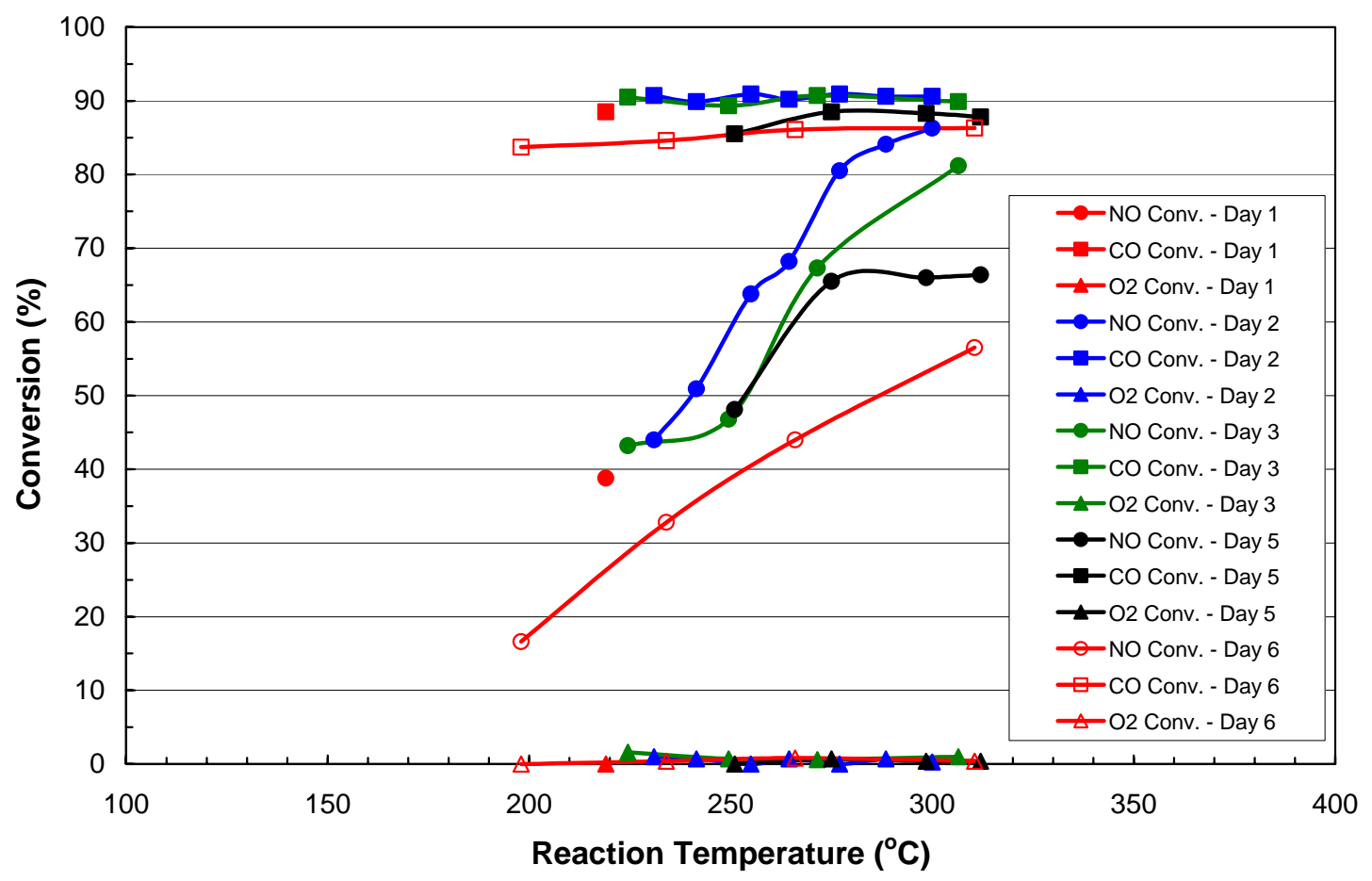

Figure $2 \mathrm{NO}, \mathrm{CO}$ and $\mathrm{O}_{2}$ Conversions over the $40 \% \mathrm{Fe} / 30 \% \mathrm{Cu}$ I AL Catalyst $\mathrm{N}$

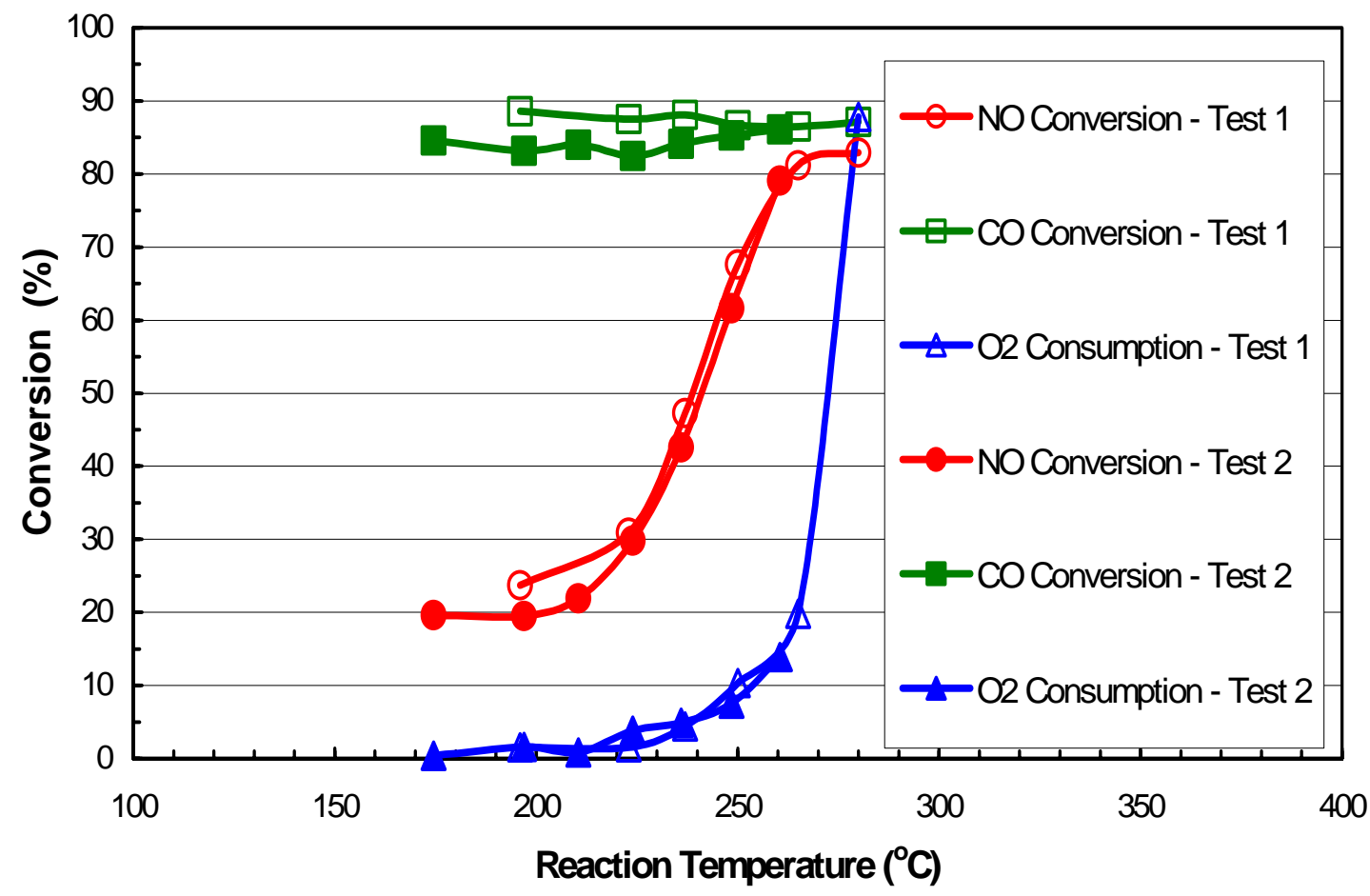

Figure 3 Conversion of $\mathrm{NO}, \mathrm{CO}$, and $\mathrm{O}_{2}$ over the $40 \% \mathrm{Fe} / 30 \% \mathrm{Cu}$ I AC Catalyst 
Oxygen Consumption: At higher temperatures, the AC based catalysts displayed significant depletion of oxygen in the reactant gas mixture, due to the partial combustion of carbon substrate (pathway 3)

As expected, the AL based Type $\mathrm{N}$ data in Figure 2 showed little $\mathrm{O}_{2}$ loss over the entire temperature range. Since the dry reactant gas mixture contains $520 \mathrm{ppm} \mathrm{CO}$ and $3 \% \mathrm{O}_{2}$, complete oxidation of all the CO (via pathway 2 above) would consume about $0.8 \%$ of oxygen in the mixture assuming it being the sole oxidant. Most test data with AL-based catalysts (N, O, P, $\mathrm{Q}$ ) have oxygen conversion in the range of $0.4-0.8 \%$, which suggests that $\mathrm{CO}$ oxidation may be the only reaction consuming oxygen.

Exposure to $\mathbf{H}_{2} \underline{\mathbf{O} / \mathbf{S O}_{2}}=$ : During Day 4, catalyst $\mathrm{N}$ was exposed to moisture and $\mathrm{SO}_{2}$. Figure 4 shows the transient data of Day 4 test.

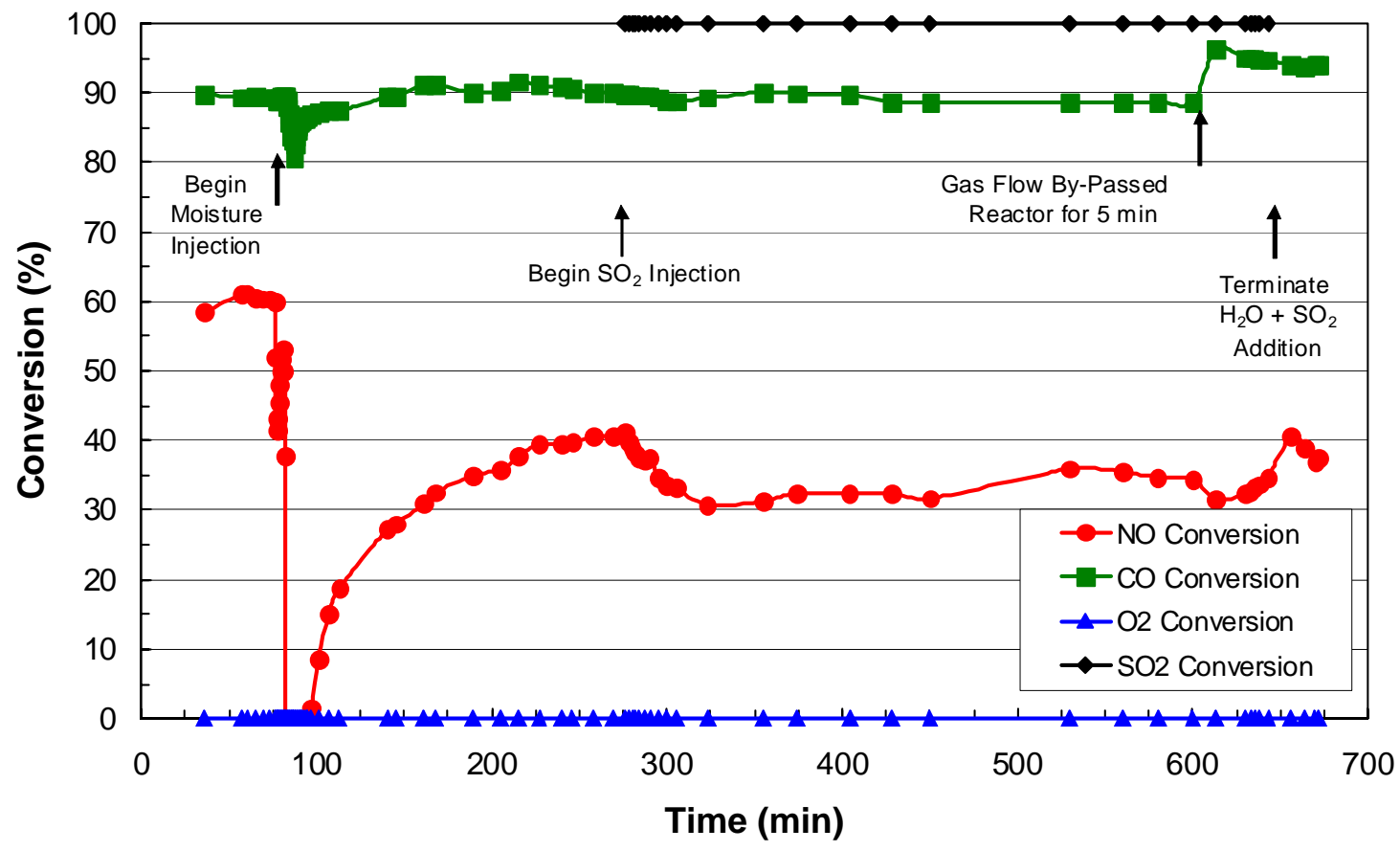

Figure 4 Historical Data of Catalyst $\mathrm{N}$ upon Exposure to $\mathrm{H}_{2} \mathrm{O}_{\mathrm{SO}}$

At the beginning, steady state conditions were reached at $275^{\circ} \mathrm{C}$ reaction temperature and in dry, $\mathrm{SO}_{2}$ free gas mixture, with a NO conversion of $61 \%$. Upon introduction of water vapor to the gas stream (8\% $\mathrm{H}_{2} \mathrm{O}$ in the mixture), a large amount of $\mathrm{NO}$ was desorbed from the catalyst. NO levels as high as $300 \%$ of the inlet concentration were measured briefly from the outlet gas. At the same time a small drop in CO conversion was observed, indicating some desorption of CO from the catalyst. Both $\mathrm{CO}$ and $\mathrm{NO}$ conversions recovered gradually with $\mathrm{CO}$ conversion restored to original level of about $90 \%$. NO conversion was slower in recovery and only reached about two-thirds of the original activity after three hours. 
Compared to AC based catalysts subjected to similar test conditions, the AL catalyst had a much larger amount of NO desorption and a larger loss of NO activity due to water addition. This is clearly shown in Figure 5, in which the NO concentrations in reactor outlet gas immediately before and during water vapor addition are plotted for several AC and AL based tests.

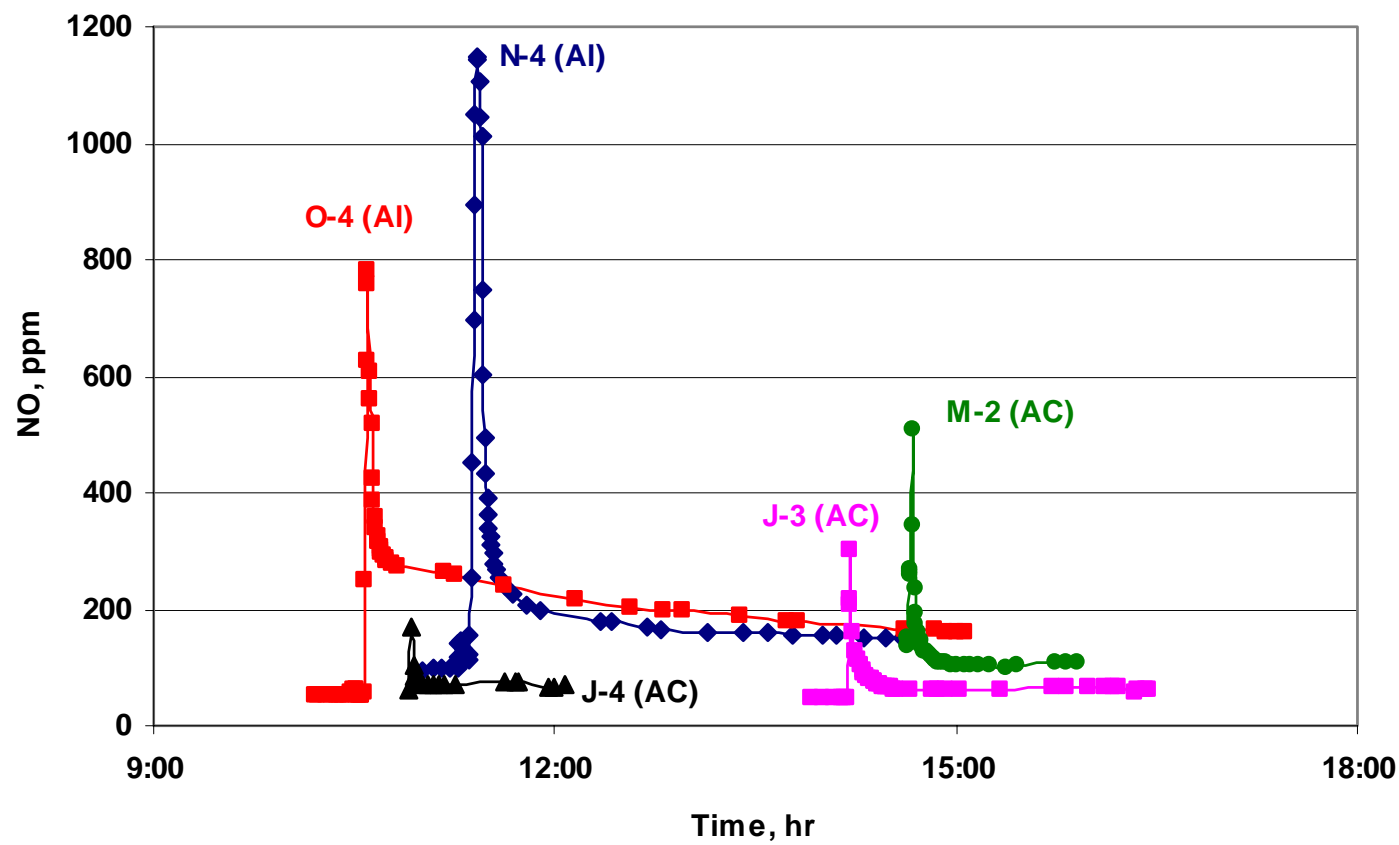

Figure 5 Transient NO Concentrations before and after the Start of Water Addition

Addition of $200 \mathrm{ppm} \mathrm{SO}$ to the reactant gas stream led to a small reduction in the NO activity. Unlike the AC based catalysts that displayed a continuous decay of $\mathrm{NO}$ activity during $\mathrm{SO}_{2}$ exposure, the activity of AL catalysts did not reduce further after the initial drop. Type $\mathrm{N}$ even regained some activity over the next several hours. The CO conversion was only slightly lowered upon introduction of $\mathrm{SO}_{2}$, and was holding steady thereafter.

Towards the end of the Type $\mathrm{N}$ testing, the gas flow to the reactor was bypassed for five minutes to measure inlet gas composition. This caused a jump in CO conversion. Terminating $\mathrm{H}_{2} \mathrm{O} / \mathrm{SO}_{2}$ resulted a small surge in NO activity, but no noticeable effect on CO conversion.

During the entire test, oxygen in the gas mixture remained unchanged. No $\mathrm{SO}_{2}$ was detected in the outlet gas. The fate of the $\mathrm{SO}_{2}$ needs be investigated in the future.

The catalyst using calcined AL support (Type O) was also exposed to $\mathrm{H}_{2} \mathrm{O} / \mathrm{SO}_{2}$ during Day 4. As seen in Figure 6, the Type $\mathrm{O}$ test data are consist with Type $\mathrm{N}$ and support the observations described above. 


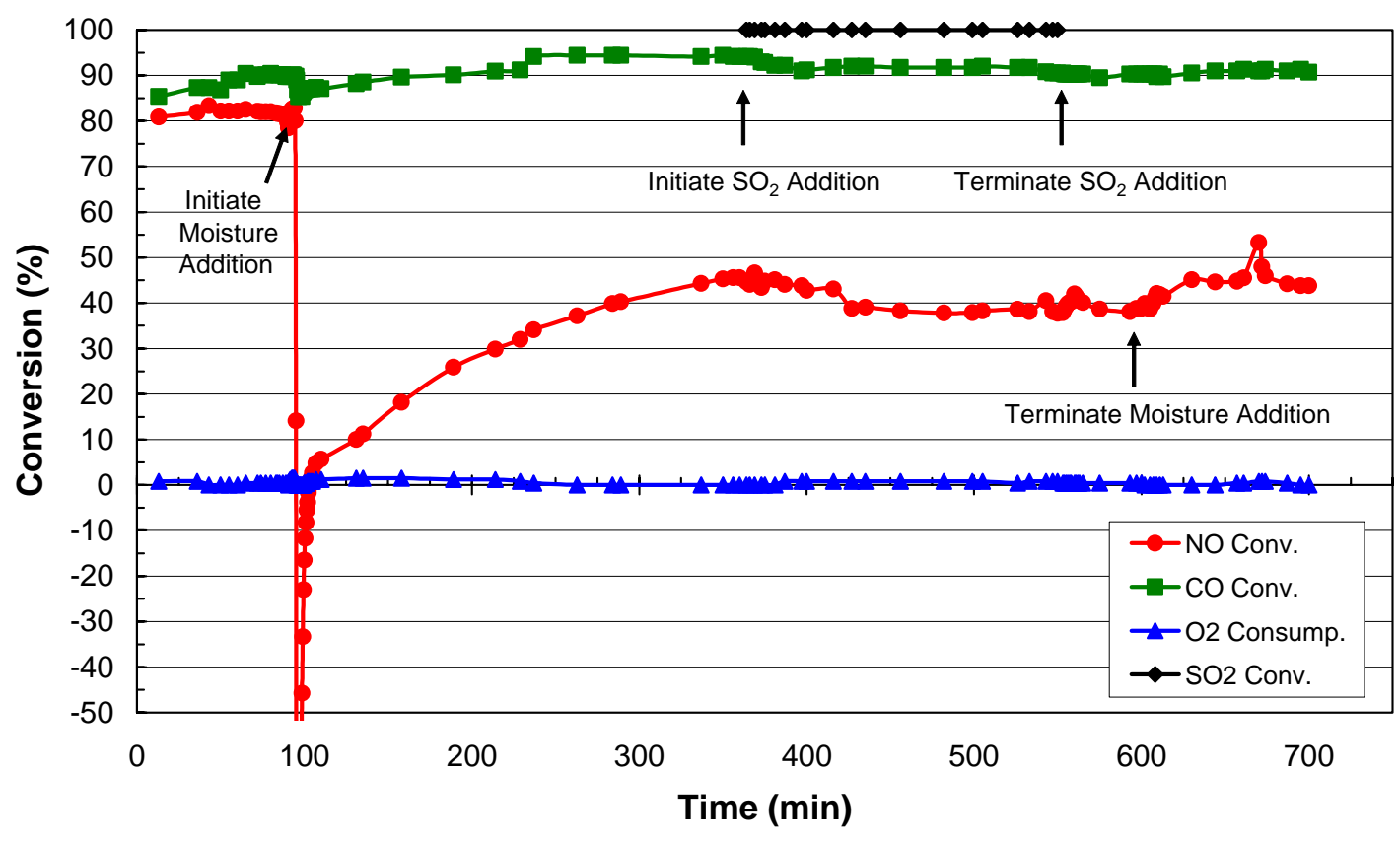

Figure 6 Historical Data of Type $\mathrm{O}$ Catalyst upon Exposure to $\mathrm{H}_{2} \mathrm{O} / \mathrm{SO}_{2}$

As Received versus Calcined AL: As described in Section 2.2, a separate catalyst sample was prepared by impregnating metals onto calcined activated alumina. The calcing of as-received AL in a furnace maintained at $500{ }^{\circ} \mathrm{C}$ overnight exhibited a $14.4 \%$ weight loss. The BET surface areas of the as-received and calcined AL and their associated catalysts are given in Table 2. Catalyst $\mathrm{O}$ with calcined AL had higher surface areas before and after the impregnation. For both catalysts, the surface areas after the tests were higher than that before the tests, indicating that the micro pore structure remained intact through testing. Type $\mathrm{O}$ had lower surface area after the the tests, possibly because $\mathrm{O}$ was subjected to more testing time (8 days versus 6 days for $\mathrm{N}$ ).

Table 2 BET Surface Area $\left(\mathrm{m}^{2} / \mathrm{g}\right)$ of Type $\mathrm{N}$ and $\mathrm{O}$ Catalysts

\begin{tabular}{|l|c|c|}
\hline & N - As Received AL & O - Calcined AL \\
\hline Before Impregnation & 127 & 162 \\
\hline Before Cat. Tests & 115 & 134 \\
\hline After Cat. Tests & 201 & 153 \\
\hline
\end{tabular}




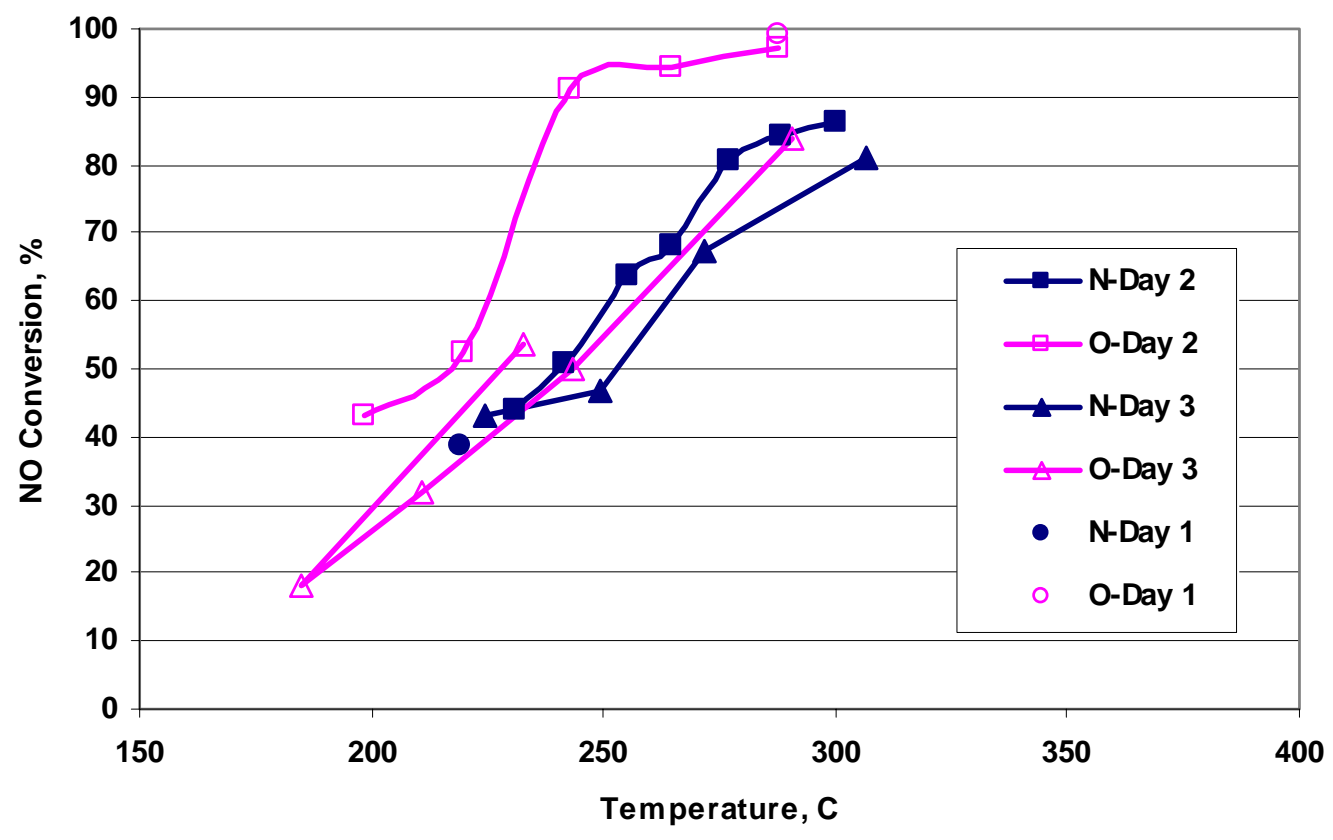

Figure 7 NO Conversion for N and O Catalysts

The behavior of Type $\mathrm{O}$ catalyst was very similar to Type $\mathrm{N}$, except that $\mathrm{O}$ had a higher initial NO activity. Figure 7 shows the NO conversion data of the first three days of testing for both $\mathrm{O}$ and $\mathrm{N}$, in dry, $\mathrm{SO}_{2}$ free gas mixture. Type $\mathrm{O}$, based calcined $\mathrm{AL}$, achieved higher $\mathrm{NO}$ conversion at lower temperature when same day test profiles are compared with each other.

Deactivation: It is clear from Figure 7 that both $\mathrm{N}$ and $\mathrm{O}$ catalysts exhibited higher light-off temperatures and lower final NO conversions for later tests. This deactivation trend is more evident in Figure 2 where five days of test data are plotted together. Although the Days 5 and 6 tests were conducted after $\mathrm{H}_{2} \mathrm{O} / \mathrm{SO}_{2}$ exposure, their data seem to fit the general deactivation trend. This level of deactivation was not observed during the earlier tests with AC based catalysts.

The fact that Day 5 test after $\mathrm{H}_{2} \mathrm{O} / \mathrm{SO}_{2}$ exposure achieved significantly higher NO conversion than Day 4 (> 65\% versus 30-40\% for Day 4) suggests that moisture and $\mathrm{SO}_{2}$ did not cause permanent damage to the catalyst and its $\mathrm{NO}$ activity were regenerable after exposure. It is also important to point out that AL based catalysts exhibited excellent and stable activity for CO reduction. The $\mathrm{CO}$ conversion of both $\mathrm{O}$ and $\mathrm{N}$ catalysts did not change significantly over time, even during and after $\mathrm{H}_{2} \mathrm{O} / \mathrm{SO}_{2}$ exposure.

$\mathbf{N}_{2}$ O Formation: As reported during previous quarters, the AC based catalysts had very high $\mathrm{NO}$ to $\mathrm{N}_{2}$ selectivity, with only minor $\mathrm{N}_{2} \mathrm{O}$ formation. The amount of $\mathrm{N}_{2} \mathrm{O}$ found in the reactor outlet gas depended strongly on the reactor temperature and the type of AC catalysts. In Figure 8, $\mathrm{NO}$ to $\mathrm{N}_{2} \mathrm{O}$ conversion data of all tests with AL based catalysts are plotted along with that of two tests of AC catalysts with the same metal loadings. No significant $\mathrm{N}_{2} \mathrm{O}$ formation was observed for AL based catalysts. This seems to suggest that the $\mathrm{N}_{2} \mathrm{O}$ formation in the current tests (either 
as a final or intermediate product of NO reduction) may be promoted by the activated carbon, rather than by the metal ingredients ( $\mathrm{Fe}$ and $\mathrm{Cu}$ ) which are common to both $\mathrm{AL}$ and $\mathrm{AC}$ catalysts.

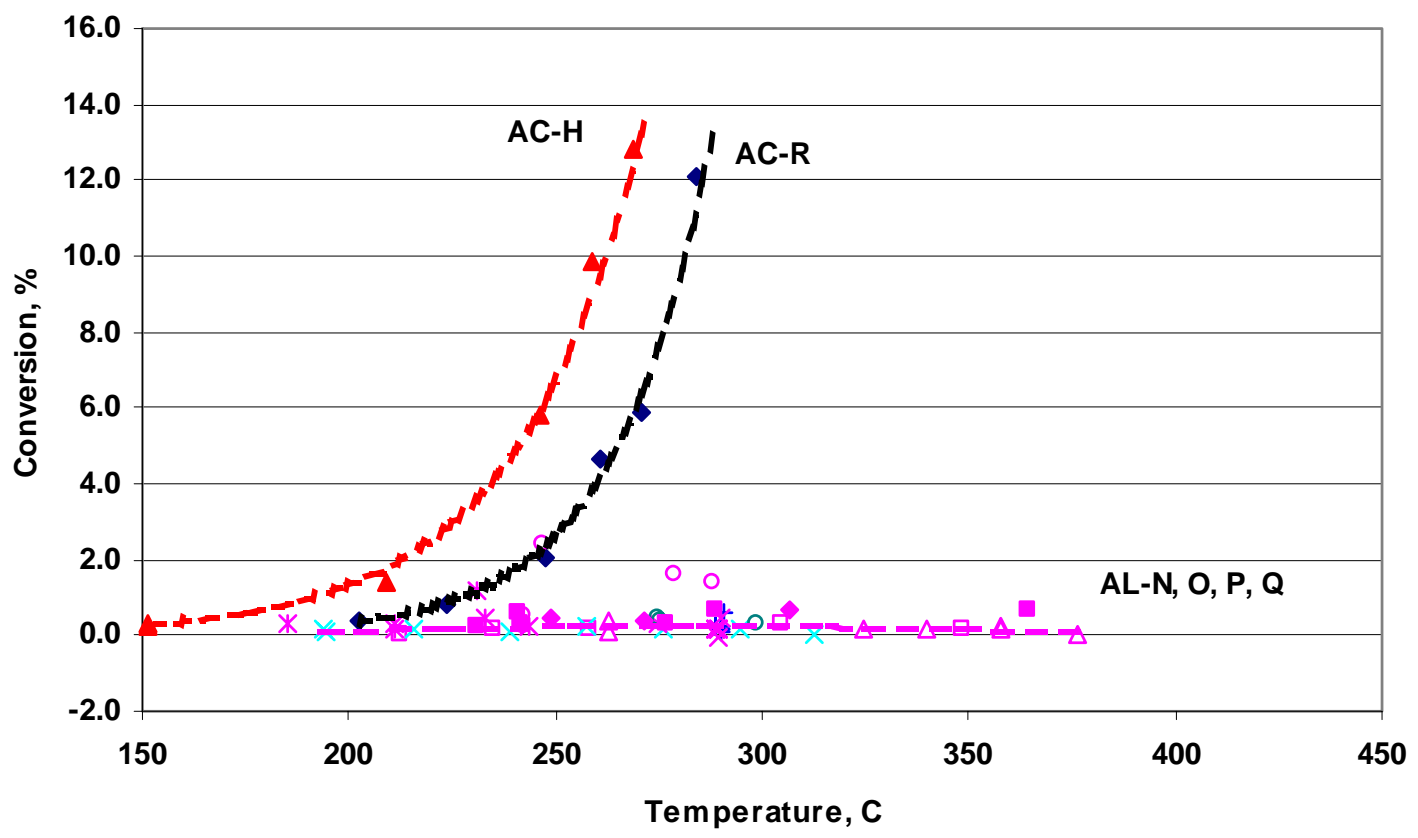

Figure $8 \mathrm{NO}$ to $\mathrm{N}_{2} \mathrm{O}$ Conversion for $\mathrm{AC}$ and $\mathrm{AL}$ Catalysts

\subsection{Testing with High Space Velocity}

Tests with high space velocities were carried out with the same flow rate of the same reactant gas mixture, as described in Section 2.3. Instead of the normal $20 \mathrm{ml}$ layer of catalysts, only $4 \mathrm{ml}$ was loaded into the reactor, resulting in a gas hourly space velocity (GHSV) of $5250 \mathrm{hr}^{-1}$ in dry, $\mathrm{SO}_{2}$ free gas mixture. This space velocity is five times the normal space velocity used in other tests. As shown in Table 1, catalyst type Q and $\mathrm{R}$ are duplicate samples of $\mathrm{O}$ and $\mathrm{H}$, used for high GHSV tests.

As seen in Figure 9, the AL based catalyst Q (a fresh duplicate of $\mathrm{O}$ ) tested at high space velocity achieved $60 \%$ NO conversion, compared to over $90 \%$ for the same catalyst tested at low space velocity. Also the NO activity curve became much flatter, and the temperature needed for 50\% NO conversion, $\mathrm{T}_{50}$, was about $60{ }^{\circ} \mathrm{C}$ higher at high space velocity. This large difference indicates that the short gas-catalyst contact time was limiting the NO conversion at the high space velocity.

The AC based catalyst, on the other hand, achieved high NO conversion at high space velocity, although higher reaction temperature was needed as indicated by a general shift of the activity curve toward higher temperatures. Recalling the reaction pathways discussed earlier, at high space velocity, a higher reaction temperature is needed to compensate for a smaller catalyst 
volume. The fact that AC based catalysts have two NO reduction pathways (1-through reaction with $\mathrm{CO}$, and 4-reaction with carbon), and both reactions speed up with higher temperature, may explain why high NO conversion was achievable by AC based, but not by AL based catalysts at the high space velocity.

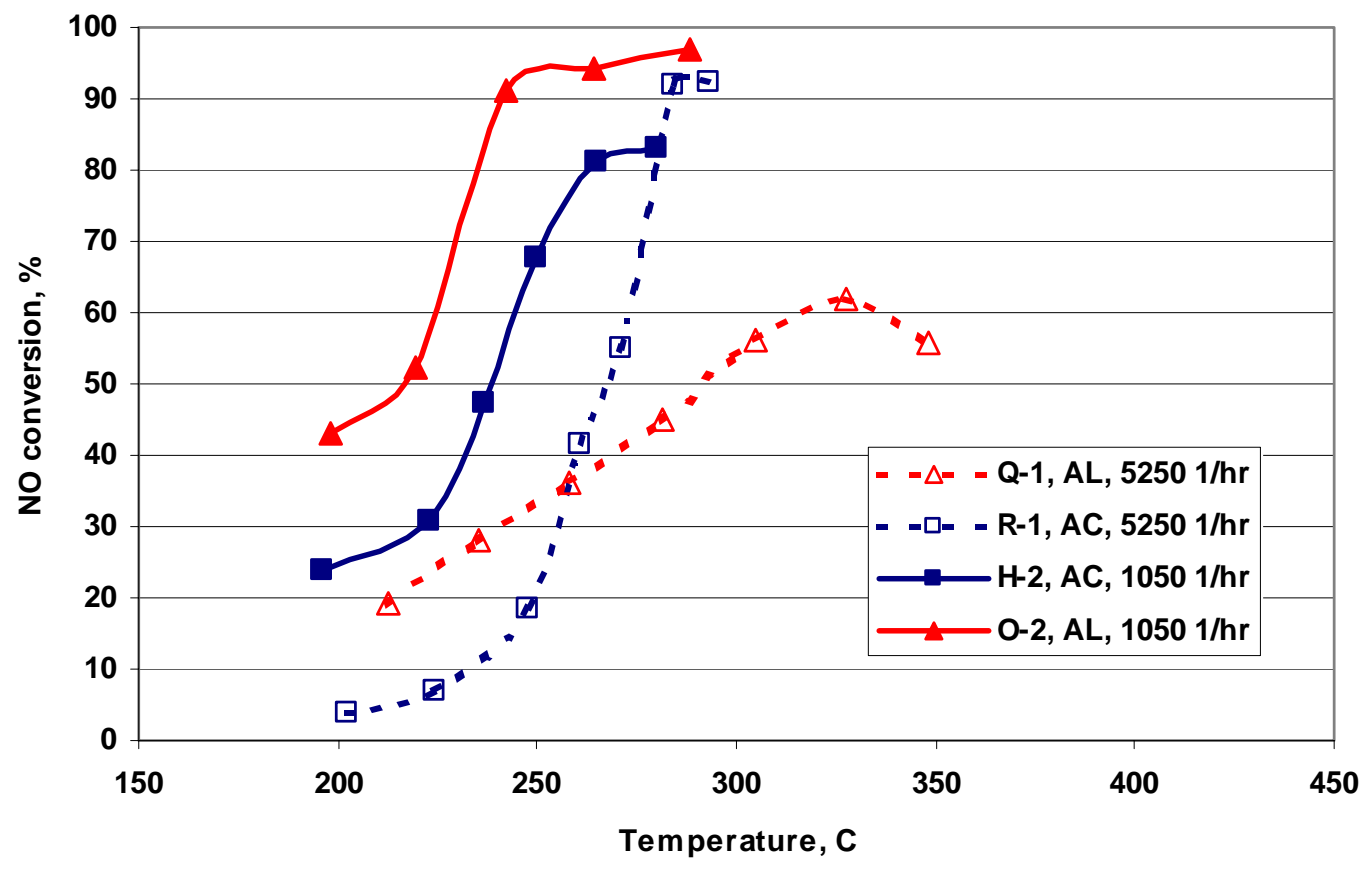

Figure 9 Effect of Space Velocity on NO Conversion for AC and AL Catalysts

Another catalyst sample tested at high space velocity is type P, which is the remaining sample of catalysts $\mathrm{O}$ after eight days of testing. Figure 10 compares the performance of type $\mathrm{P}$ with that of type Q (fresh duplicate sample of type O).

As can be expected from earlier discussions of deactivation for AL based catalysts, the previously tested type $\mathrm{P}$ had its activity profile shifted about $40^{\circ} \mathrm{C}$ towards higher temperature, and achieved lower final NO conversion. It is also interesting to note that, with increasing reaction temperature, the NO conversion of both $\mathrm{P}$ and $\mathrm{Q}$ reached a maximum and then decreased with further increase in temperature. A possible explanation for this is that at high temperatures, the rapid oxidation of $\mathrm{CO}$ by oxygen (reaction pathway 2) may have depleted the $\mathrm{CO}$ needed for NO reduction (pathway 1). This maximum NO conversion was generally not observed for AC based catalysts, because NO is converted by the dual reactions with $\mathrm{CO}$ and carbon (pathways 1 and 4), and also at high temperatures CO generated through burning of carbon substrate (pathway 3) more than replenishing the depletion due to pathway 2. 


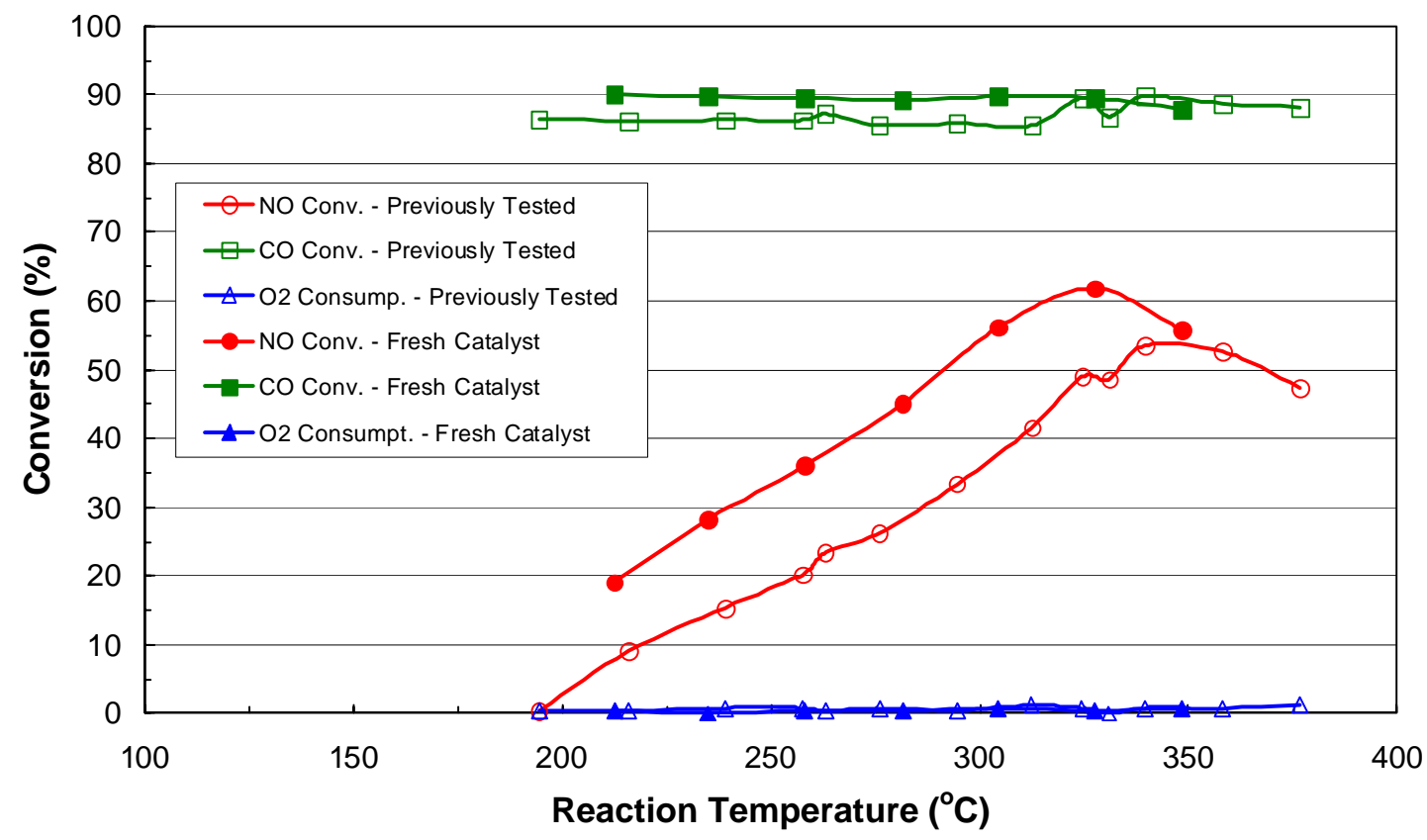

Figure $10 \mathrm{NO}, \mathrm{CO}$ and $\mathrm{O}_{2}$ Conversions over Previously Tested $(\mathrm{P})$ and Fresh (Q) $40 \% \mathrm{Fe} / 30 \% \mathrm{Cu}$ /AL Catalyst with GHSV = $5250 \mathrm{hr}^{-1}$

Even at the higher space velocity, the CO conversion remained very high during entire reaction temperature range, and the previously tested catalyst showing only slightly lower CO conversion. As with earlier AL-based catalyst testing, no significant oxygen consumption was observed. 


\subsection{CONCLUSION}

Although precious metal catalysts have been successfully applied in the automobile industry to convert NO with CO and hydrocarbons as reductants, they require a reducing environment as typically found in the gasoline engine exhaust, and therefore are not suitable for power plant flue gas applications, where oxidizing conditions must be maintained for safety and efficiency considerations. The base metal catalysts, prepared and tested in this study, exhibited very promising NO conversion under simulated power plant flue gas conditions, including 3\% oxygen. This is a crucial step towards a practical, ammonia-free, catalytic NOx reduction system for combustion power plants.

The experimental work of the current quarter with catalysts made from deposited transition metals on activated alumina support has led to the following observations:

- NO reduction in the range of $80-90 \%$ (outlet NO only 25-50 ppmv) was achieved with operating temperature ranging from $230-310^{\circ} \mathrm{C}$.

- The AL based catalysts also reduced over $80-90 \%$ of the CO in the gas mixture. The CO conversion level was not significantly affected by temperature, gas composition or test duration in the ranges tested.

- Unlike AC based catalysts that generated a small mount of $\mathrm{N}_{2} \mathrm{O}$, no significant $\mathrm{N}_{2} \mathrm{O}$ formation was observed during the tests with AL based catalysts.

- The AL based catalysts behaved differently than AC based catalysts when exposed to moisture and $\mathrm{SO}_{2}$. Addition of water vapor to the reaction gas caused temporary desorption of NO from the AL based catalyst, which is followed by lowered NO conversion. Subsequent $\mathrm{SO}_{2}$ addition to the gas mixture caused a small reduction in $\mathrm{NO}$ conversion, but the conversion remained stable during $\mathrm{SO}_{2}$ exposure after the initial impact.

- After the $\mathrm{H}_{2} \mathrm{O} / \mathrm{SO}_{2}$ exposure, cooling with $\mathrm{N}_{2}$ purge and reheating for new test, the NO conversion activity of $\mathrm{Fe} / \mathrm{Cu} / \mathrm{AL}$ catalysts was restored to near original levels in dry, $\mathrm{SO}_{2}$ free gas. The AL based catalysts showed a stronger deactivation tendency than AC based catalysts.

- Both $\mathrm{Fe} / \mathrm{Cu} / \mathrm{AC}$ and $\mathrm{Fe} / \mathrm{Cu} / \mathrm{AL}$ catalysts were tested with a high space velocity of $5250 \mathrm{hr}^{-1}$. The AC based catalysts achieved over $90 \%$ NO conversion at a higher reaction temperature. The AL based catalyst reached a maximum NO conversion of about $60 \%$. CO conversions of $80-90 \%$ were achieved for both AC and AL catalysts despite the high space velocity.

In summary, the AL supported base metal catalysts have shown very promising NO conversion and selectivity in oxidizing environment with $\mathrm{CO}$ as reductant, as well as excellent $\mathrm{CO}$ reduction. It is recommended that both the AL and AC groups of catalysts be further developed and tested at pilot scale, for long duration, and with actual combustion flue gas. 